\title{
Katherine Mansfield, 1888-1923
}

\author{
Joanna Woods
}

Katherine Mansfield is one of New Zealand's most celebrated authors and enjoys a widespread international following. With her contemporaries, James Joyce and Virginia Woolf, she forms part of the literary avant-garde whose innovations in the second and third decades of the twentieth century signalled the emergence of modernism. Her reputation rests on a collection of eightyeight deceptively simple short stories, in which she pioneered many new literary techniques and exerted an important influence on the evolution of the short story in English.

In her writing Mansfield breaks away from the conventions of nineteenth century fiction by dispensing with the independent voice of the narrator and by reducing plot to a minimum. Her focus is on the inner world rather than on external action, and much of the narration is located within the minds of her characters. Mansfield's place in Western literature has been assured by her technical achievements, but she owes her lasting popularity with her readers to the elegance and wit of her writing. Her stories are a brilliant evocation of a bygone, Edwardian world, in which childhood memories, loneliness, and the complexity of human relationships are recurring themes. Her prose is noted for its economy and compression, and she presents her artistic vision through a series of meticulously crafted impressions, enlivened by often-mischievous imagery. Mansfield left New Zealand in 1908, aged nineteen, and spent most of her adult life in England and France, but her New Zealand heritage played a crucial role in her creative development and inspired many of her finest stories.

Katherine Mansfield was born in Wellington, the capital of New Zealand, on 14 October 1888. She was the third child of Harold and Annie Beauchamp and was christened Kathleen. Her second name was Mansfield, the maiden name of her maternal grandmother, which she later adopted to form the pseudonym 'Katherine Mansfield.' The family origins of her parents were predominantly British-although there was some distant Huguenot blood in Harold's ancestry-and both of them were born in Australia. Harold first came to New Zealand at the age of two, when his father decided to abandon his unsuccessful career as a 'general merchant' in the Australian gold fields in favour of an equally restless life in New Zealand. In 1876, at the age of eighteen, Harold started work as a clerk with an importing firm in Wellington. Unlike his father, however, he had the ability and energy to establish himself 
in business and by the time Kathleen was born, he was already prosperous. He later went on to become the Chairman of the Board of the Bank of New Zealand and to play a prominent role in the commercial life of Wellington. He was knighted in 1923 for his financial services to New Zealand.

Annie Beauchamp was born Annie Burnell Dyer. Her mother's family, the Mansfields, had been Sydney publicans and her father, Joseph Dyer, worked in insurance. After Annie's birth in 1864, her parents moved to New Zealand where her father set up the Wellington branch of an Australian insurance company. Annie first met Harold when she was thirteen and in 1884, after a lengthy courtship, they married. Contemporary photographs show Annie as an attractive and elegant woman, but she suffered from frequent ill health and had little of her husband's vitality.

Mansfield frequently portrays her parents in her writing. In two of her bestknown New Zealand stories, 'Prelude' (1918) and 'At The Bay' (1922), Harold appears in the guise of the self-important Stanley Burnell, while Annie, as Linda Burnell, is depicted as an indifferent and distant mother. In 'The Garden Party' (1922), Mansfield's portrait of her mother as Mrs Sherldan is rather more sympathetic, but it still emphasises the gulf that she felt existed between her and the rest of her family. The only member of the Beauchamp household who seems to have understood her complex personality and to have responded to her demands for love, was her grandmother, Margaret Mansfield Dyer. This may well be one of the reasons why Kathleen later chose to write under her grandmother's name.

Kathleen's conviction, from early childhood, that she was an outsider in her own family initially stemmed from her position as the third of four daughters of parents who longed for a son. When her only brother, Leslie, was finally born in 1894, the family fell into two groupings. Kathleen's two elder sisters, Vera and Charlotte, who were born in 1885 and 1887 respectively, formed a natural partnership at the top of the family. A fourth daughter, Gwendoline, died in 1891 aged three months, while Jeanne (who was four years younger than Kathleen), and Leslie were always affectionately regarded as 'the babies'. Consequently, Kathleen found herself isolated in the middle of the family with no particular ally of her own

Kathleen's sense of alienation, however, was not simply due to her lack of a special position in the family hierarchy. It was also a question of personality. Highly intelligent and with precocious powers of observation, Kathleen was quick to note that she did not have exclusive rights to the affections of her parents. She longed to occupy centre stage and in her efforts to assert herself, she became moody and difficult. Her acute sensitivity and her desire to excel-the very qualities that contributed so much to her later success as a writer-further exacerbated her feelings that she was a misfit. 
Despite her psychological isolation, Kathleen had a carefree and privileged childhood. Harold's growing prosperity ensured that his five children enjoyed the best that money could buy. When Kathleen was four and a half, her parents moved from their relatively modest house at 11 Tinakori Road, in which Kathleen had been born, to a rambling country establishment a few kilometres outside the city. The house, which was in the suburb of Karori, had a large garden with an orchard and enough land to justify keeping cows, pigs chickens and horses. Kathleen revelled in these new surroundings and they later became the setting for 'Prelude'.

Kathleen's formal education began in 1895 when she attended the Karori village school. Her love of writing was soon in evidence, and in 1897 she won the school prize for English composition with a piece entitled 'A Sea Voyage'. She also read avidly and a contemporary photograph shows her as a plump and solemn child in unbecoming, steel-rimmed spectacles. In mid-1898 Kathleen was enrolled at the more sophisticated Wellington Girls' High School. A few months later the Beauchamps left Karori and returned to Wellington. Harold had just been appointed by the New Zealand Premier, Richard Seddon, as one of the directors of the Bank of New Zealand and, in keeping with his new status, he moved his family to an impressive mansion at 75 Tinakori Road, not far from their earlier home.

At her new school Kathleen's academic abilities became apparent at an early stage. She won prizes for English, Arithmetic, and French and two pieces by her, signed 'Kathleen Beauchamp', appeared in the school magazine. In June 1900, however, Harold and Annie decided to move their three elder daughters to an exclusive private school called Miss Swainson's. For Kathleen, this change of schooling coincided with the onset of adolescence. As she matured, both physically and mentally, she lost her childhood plumpness and embarked on her lifelong habit of recording her innermost feelings in a series of notebooks. Her interest in writing continued and she wrote poetry as well as founding a school magazine. Despite her intellectual talents, however, Kathleen had few close friends. Both at home and at school, she continued to feel like an outsider and her emotions were frequently in a state of turmoil.

In 1902 Kathleen found a focus for her adolescent yearnings. She fell in love with a young musician named Arnold Trowell, who was a brilliant cellist. The romance was largely in her own mind, but it encouraged her already strong interest in music and led her to believe, for the next six years, that music was her true vocation. Harold, meanwhile, had decided that his three elder daughters would benefit from further education in London, and on 29 January 1903 all seven members of the Beauchamp family, accompanied by Annie's brother and sister, Sydney and Belle Dyer, set sail for England on a 
small steamship called the Niwaru. After visiting family and friends, Harold, Annie, and the two younger children returned to New Zealand, but for the next three years Kathleen and her two elder sisters remained in London as pupils at a select school for girls called Queen's College, Harley Street.

The wide-ranging education that Kathleen received at Queen's played a vital role in her intellectual development. She read voraciously, and the list of authors that she proposes to young New Zealanders on her return to Wellington gives a good indication of the breadth of her interests. Among those she recommends are: William Morris, Catule Mendès, George Meredith, Maurice Maeterlinck, John Ruskin, Rodenbach, Le Gallienne, Arthur Symons, Gabriele D'Annunzio, George Bernard Shaw, Granville Barker, Sebastian Melmouth, Walt Whitman, Leo Tolstoy, Edward Carpenter, Charles Lamb, William Hazlitt, Nathaniel Hawthorne, and the Brontës.

With her precocious mind and her literary abilities, Kathleen soon attracted the attention of the German master, Walter Rippmann. Rippman took a keen interest in the Queen's College Magazine, to which Kathleen contributed, and he encouraged her to expand her literary horizons by reading the works of modern authors with 'decadent' and symbolist overtones. Foremost among these was Oscar Wilde, whose work began to exert a strong influence on her outlook. Throughout her time at Queen's, however, Kathleen's chief interest was music and while she continued to write poems and sentimental stories about children in her notebook, her ambition was to become a professional cellist.

At Queen's Kathleen also formed some close friendships with her fellow pupils and inspired the lifelong devotion of a lonely girl named Ida Constance Baker, who later took on the thankless task of being Mansfield's domestic helper. Kathleen still believed that she was in love with Arnold Trowell (who was always known as Tom), and she had a schoolgirl passion for Rippmann, but there is also evidence that under the sway of Wilde, she began to develop an interest in her own sex. In April 1906, when Harold and Annie arrived in London to bring their daughters home, they found Kathleen difficult to manage. Thanks largely to Rippmann, she had tasted an intellectual freedom that was quite beyond the comprehension of her more conventional family. She longed to stay in London to pursue her musical career, but her father refused his permission, and so she decided to devote herself to writing. On the return voyage to Wellington, she documented her constant clashes with her parents in her notebook, in which she also refers, in lurid, Wildean language, to some of her sexual encounters aboard ship.

On 6 December 1906, after six weeks at sea, the Beauchamps arrived back in Wellington. By January they had moved to another large house at 47 Fitzherbert Terrace, in which Annie entertained regularly. In the gossip 
columns of the local papers, the musical accomplishments of the three Misses Beauchamp are admiringly reported and throughout the next eighteen months, Kathleen's presence at social occasions is regularly recorded in the Wellington press. But although she went through the motions of participating in local society, her notebook entries at this time reveal her inner frustration. After three years in the stimulating, intellectual atmosphere of London, she felt stifled by family life and found few people in Wellington who shared her literary interests. She was determined to become a writer, and she spent many hours in her room writing in her notebook and working on a semiautobiographical novel-which she never finished-called Juliet. She continued to read widely, availing herself of the reading rights which Harold had acquired for her at Wellington's General Assembly Library.

At this stage Kathleen was still experimenting with a variety of literary genres. She planned a book of child stories with a woman friend nine years her senior named Edith Bendall, but their friendship developed into a love affair and the projected book was never completed. The affair with 'Edie' was followed by a similar relationship with an earlier schoolmate at Miss Swainson's, the beautiful Maori heiress, Maata Mahupuku. Kathleen's notebooks also record flirtations with men and in a letter to an English cousin, she claims to have received five proposals of marriage.

Throughout this turbulent period in her life, however, writing was always foremost in her mind. In October 1907 three descriptive pieces by her, entitled 'Vignettes', appeared in a Melbourne journal called the Native Companion. The 'Vignettes', whose overblown style was strongly influenced by Wilde, were Kathleen's first adult publications. This was also the first occasion on which she used the pseudonym 'K. Mansfield'. In November and December 1907 the Native Companion published further examples of her work, including a short story called 'In a Café'. Although the writing is immature, 'In a Cafe' already displays many of the key elements of Mansfield's later work. The plot is slight-an encounter between a young couple in which they toy with the idea of marriage-and the interest is focused on the girl's emotions. There is little external action and the characterisation is achieved through the presentation of carefully selected detail and dialogue. The climax of the story comes at the deciding moment when the heroine realises that her admirer has thrown away her gift of violets.

Part of the success of these early literary endeavours was due to the support of Harold. When he learned that the editor of the Native Companion doubted the authenticity of the 'Vignettes', he wrote to him, without Kathleen's knowledge, confirming that she was their author and expressing his belief in her ability to write. Harold also found an imaginative solution to Kathleen's boredom with conventional social life by organising for her to take a month- 
long camping trip in the North Island of New Zealand. This hollday gave Kathleen a vivid experience of New Zealand's natural beauty, which she not only cherished for the rest of her life, but also drew on for literary material. Her memories of the summer cottage rented by Harold at Day's Bay were an even greater source of literary inspiration. Lying in unspoilt native bush on the east side of Wellington Harbour, this cottage forms the background to her story 'At the Bay'.

During 1908 some minor pieces by Kathleen appeared in New Zealand publications, but she continued to rebel against life in Wellington and eventually persuaded her parents to allow her to move to London to pursue a literary career. On 6 July 1908, aged 19, she set sail alone for England and never returned to New Zealand. During her first months in London, Kathleen was unhappy and short of money. She had no literary contacts, or knowledge of the literary world, and her only income was an annual allowance of $£ 100$ from her father. She lived in a room in a hostel for music students in Paddington and spent her days trying to write. According to her biographer, Antony Alpers, her story, 'The Tiredness of Rosabel', dates from this time. The story, which was first published in 1924, describes a day in the life of a poor shop girl who imagines a fairy tale romance with a handsome, male customer. The action moves between the past, the present, and an imaginary future and is an early example of Mansfield's sophisticated management of different time levels.

Within a few weeks of her arrival, Kathleen was driven by loneliness and homesickness to seek out the Trowell family, now resident in London. The affections of Arnold Trowell, whom she had so much admired, were engaged elsewhere, but Kathleen soon embarked on a passionate love affair with his twin brother, Garnet, and by early 1909 she was expecting his child. Nothing suggests that either Garnet or his parents were aware of the pregnancy, but the Trowell parents disapproved of the relationship and persuaded their son to break it off. Kathleen, meanwhile, entered into a hasty engagement with a man whom she barely knew, a singing teacher named George Bowden, who was similarly unaware of her condition. On 2 March 1909 she and Bowden were married at Paddington Register office with her faithful school friend, Ida Baker, as the only witness. That night, before the marriage had been consummated, Kathleen abandoned her husband. She later had a brief reunion with Garnet, who was on tour as a musician with the Moody-Manners Opera Company.

News of Kathleen's marriage and desertion soon reached her parents in Wellington. On 27 May 1909 Annie arrived in London where she met with Bowden, who believed that the failure of the marriage had been caused by a lesbian relationship between Kathleen and Ida. Ida was despatched for a 
hollday in the Canary Islands, while Annie and Kathleen set off for a small spa in Bavaria called Bad Wörishofen. After a few days Annie left Kathleen and reembarked for New Zealand. Although there is no evidence that she knew of her daughter's pregnancy, on her return home Annie cut Kathleen out of her will. In late June, Kathleen had a miscarriage, but she remained in Bad Wörishofen for a further six months and embarked on a series of short descriptive stories, or 'sketches', based on her experiences as a guest at a German 'pension'. These stories were among the first of Mansfield's works to appear in England and formed the basis of her first collection, In a German Pension (1911).

While she was in Bavaria, Kathleen became friendly with a group of Polish intellectuals and formed a close relationship with a twenty-eight-year-old literary critic and translator named Floryan Sobieniowski. Floryan is credited with introducing Kathleen to the short stories of the Russian writer, Anton Chekhov, probably in German translation. Chekhov was the single, greatest literary influence on Mansfield's writing, and his name appears frequently in her letters and notebooks. Throughout her subsequent career as a writer, she studied his stories and techniques and sought to emulate his achievements. Chekhov died from tuberculosis in 1904, and when in 1917 Mansfield was diagnosed with the same disease, it further increased the bond she felt with him.

After her return to London in January 1910, Kathleen stayed briefly with Bowden, who introduced her to A. R. Orage, the editor of a socialist weekly called the New Age. At this time the New Age was considered to be one of the liveliest, intellectual publications in London, with articles by Hilaire Belloc, G. K. Chesterton, George Bernard Shaw, and H. G. Wells appearing regularly in its pages. Over the following year and a half, Orage published twelve of Mansfield's stories, including her 'Pension Sketches' and a number of humorous contributions and poems. Only three minor pieces were published elsewhere. By now all traces of Wilde's influence had vanished from Mansfield's work, and in much of her writing she adopts a new, satirical stance encouraged by her friendship with Orage's sharp-tongued mistress, Beatrice Hastings, with whom she occasionally collaborated.

Mansfield's first collection, In a German Pension, was published on 11 December 1911. It contained thirteen stories, seven of which revolve around her life at the pension. The 'Pension Sketches' are satirical in tone and represent the Germans as boorish and chauvinistic. In 'Germans at Meat' and 'The Luft Bad', Mansfield mercilessly mocks German attitudes to food and the digestive processes; in 'The Baron' she targets snobbery; and in 'The Advanced Lady' she imputes an array of unattractive characteristics to her fellow-guests, ranging from sentimentality to greed. The writing is marred by 
the commentary of an intrusive, first person narrator, whose arch style is reminiscent of the work of Mansfield's cousin, Elizabeth von Arnim. Elizabeth von Arnim was born Mary Annette Beauchamp and her book, Elizabeth and her German Garden, published in 1898, became a best-seller.

In three of the six remaining stories in the collection, the themes of peasant life and childbearing are presented with a brutal realism that recalls Chekhov's handling of the same subjects. 'The Child-Who-Was-Tired', which had already appeared in the New Age, describes the suffocation of a baby by an exhausted nursemaid and was identified by Elizabeth Schneider in 1935 as a copy of Chekhov's 'Sleepy'. In 1951 this story became the subject of a heated correspondence in the Times Literary Supplement, which considerably damaged Mansfield's reputation and led to accusations of plagiarism. 'Frau Brechenmacher Attends a Wedding' is a chilling portrayal of a village woman's subjugation to her husband and is considered to be the best story in the collection. 'At Lehmann's' documents the burgeoning sexuality of a young woman, whose first sexual encounter is interrupted by the screams of her employer's wife in childbirth. Sexuality also emerges as a recurring theme in 'The Swing of the Pendulum' and 'A Blaze'. In 'A Birthday' the figure of Andreas Binzer is the first of her many portrayals of her father and the subject is once again childbirth, this time Mansfield's own birth in Wellington, sketchily transposed to a German setting.

In a German Pension is not Mansfield's best work, and in 1920 she strongly resisted her publisher's proposals for a new edition. Nevertheless, in many of the stories, the imprint of Mansfield's developing literary talents is visible. Her gift for dialogue is strongly in evidence throughout and in stories such as 'A Birthday' and 'The Swing of the Pendulum', she minimises the intrusion of an independent authorial voice and breaks new ground by moving the action to within the minds of her characters through the use of interior monologue .

Despite its shortcomings, the collection was well-received and helped to establish Mansfield's reputation in the London literary world. Reviewers admired the cleverness of her writing and described her style as 'impish', but the success of In a German Pension was due, in part, to its anti-German sentiments, which struck a chord with British readers at a time when they feared a German invasion.

In late March 1910 Mansfield suffered a severe attack of what she believed to be 'peritonitis'. After a painful operation, she was rescued from a dingy nursing home by Ida, who took her to convalesce by the sea. At the time she appeared to make a complete recovery, but for the next eight years she continued to be plagued by unexplained pains, which she attributed to rheumatism. She only discovered in 1918 that the true cause of her illness was gonorrhoea, probably contracted from Floryan. 
Increasingly Mansfield began to move in the circle of writers and intellectuals to which she had been introduced by Orage and Hastings. Her private life was Bohemian. She lived alone and had a number of male admirers and several affairs. She also adopted a variety of poses and disguises and, in response to the wave of Russophilia that was sweeping Europe at this time, began to use Russian variations of her name, such as Katya and Katerina. Only her girlhood acquaintances continued to call her 'Kass' or Kathleen. During the summer of 1911 Harold and Annie brought their family to London for the coronation of King George V. A reconciliation seems to have taken place between Mansfield and her parents, but she continued to lead a very independent life and her seventeen-year-old brother, Leslie, was the only member of her family to whom she felt close.

In December 1911, shortly after the publication of In a German Pension, Mansfield sent a crime story called 'The Woman at the Store' to the editor of a radical, new magazine called Rhythm. The story, which is set in New Zealand, so impressed John Middleton Murry, the twenty-two-year-old Oxford undergraduate who edited Rhythm, that he asked a mutual friend to introduce him to the author. A few weeks later a dinner party was arranged at which Mansfield and Murry met. Murry was captivated by Mansfield's elegance and intelligence and they instantly struck up a friendship. Before long Mansfield had persuaded him to leave Oxford, and in April 1912 he became her lodger. Within a few weeks, their friendship had turned into the most enduring love affair of Mansfield's life and eventually led to marriage.

Mansfield's involvement with Murry had professional repercussions. Orage and Hastings turned against her and she stopped contributing to The New Age. Instead she joined Murry as his assistant in the publication of Rhythm. During the second half of 1912 and early 1913, Mansfield wrote a wide range of stories, poems, and reviews for Rhythm and its short-lived successor, Blue Review. Her reviews already display the critical skills which she later exercised in 1919 and 1920 as a book reviewer for the Athenaeum. Her poetry is of minor interest-its most curious aspect being the Russian pseudonym, Boris Petrovsky, under which some of it was written. Mansfield's fascination with Russia also emerges in a series of pseudo Russian pieces entitled 'Tales of a Courtyard', whose focus on low life and crime has strong echoes of Dostoevsky.

In addition to 'The Woman at the Store', Mansfield wrote two further New Zealand stories for Rhythm called 'Ole Underwood' and 'Millie', which also deal with low life and crime. 'The Woman at the Store' is a gripping tale of murder in the rugged back blocks of New Zealand, in which Mansfield adopts a naturalistic approach and successfully exploits the interplay between the menacing landscape and the sinister figure of the woman. In 'Ole Underwood' 
the central figure is a vagrant former sailor, whose mind has become unhinged after spending twenty years in prison for the murder of his wife. Mansfield uses the sordid, urban environment to intensify the atmosphere and captures Ole Underwood's insanity by moving the viewpoint in and out of his demented consciousness. 'Millie' is the grim story of a manhunt, in which the plot unfolds through a combination of interior monologue and external narration.

All three of these stories show Mansfield exploring the possibilities of naturalism and responding to the contemporary vogue for 'savagery', which found its artistic expression in the savage 'Fauve' paintings of the Post Impressionists. Her engagement with savagery and naturalism, however, was a passing phase-not unlike her earlier fascination with Wilde-and there is evidence from other stories written at this time that she was moving towards a new style that was entirely her own. Two slight stories from this period foreshadow the prominence of childhood memories in Mansfield's later writing. In 'The Little Girl' the figure of Kezia, who is Mansfield as a child and is the central consciousness of 'Prelude', makes her first appearance. In 'New Dresses' Mansfield highlights her childhood feelings of injustice and rejection. A third story, 'How Pearl Button was Kidnapped', in which Mansfield successfully sustains the viewpoint of a small child, is of greater interest and has the additional merit of being the only portrayal of New Zealand Maoris in Mansfield's writing.

Mansfield's stories for Rhythm and Blue Review were written against a backdrop of financial and domestic uncertainty. She soon discovered that Murry's naïveté in business matters had landed Rhythm heavily in debt with its printers, and she persuaded her own publisher, Stephen Swift, to take over publication. In September 1912, in a mood of optimism, she and Murry left London and rented a house in the English countryside, near Chichester. There, among others, they entertained Rupert Brooke and Eddie Marsh, who was a wealthy patron of the arts and worked at the Admiralty as the private secretary of Winston Churchill. In October, however, Stephen Swift was declared bankrupt and he absconded to Europe leaving Murry responsible for Rhythm's debts. Murry and Mansfield had to give up their house in the country and returned to a one-roomed apartment in London's Chancery Lane where they struggled to keep Rhythm afloat. Mansfield pledged her annual allowance from her father to pay the printers, and she and Murry expended much of their energy seeking revenue from advertisements. Their courageous stance won the admiration of London's literary world, and by early 1913 a group of distinguished artists and writers had offered to contribute their work to Rhythm free of charge. Among these were Rupert Brooke, Gilbert Cannan, Hugh Walpole, Frank Swinnerton, Lord Dunsaney, and D. H. Lawrence. 
In March 1913, plagued by ill health, Mansfield moved to a cottage in a Buckinghamshire village. She was also being troubled by Floryan, who had been in England for some time and was in financial difficulties. He now revealed that he had retained Mansfield's earlier love letters to him and was prepared to use them as blackmail. At this stage Mansfield managed to placate him, but in 1920 he succeeded in extracting $£ 40$ from her for the letters-a sum which equalled her advance from the publisher, Constable, for her second collection Bliss.

The final issue of Rhythm was published on 15 March 1913 and was succeeded in May by the Blue Review, in which Mansfield is listed as Associate Editor. Max Beerbohm, Walter de la Mare, D. H. Lawrence, and Hugh Walpole contributed to the first edition, which also contained a minor story by Mansfield called 'Pension Seguin'. Despite its distinguished supporters, the Blue Review survived for only three issues and in July, much to the relief of Mansfield and Murry, it collapsed. For them, the most significant outcome of their association with the Blue Review was the friendship to which it led with D. H. Lawrence and Frieda Weekley. Their first meeting took place in June 1913, when Lawrence and Frieda called on the offices of the Blue Review. The two couples instantly warmed to each other and a few weeks later, they spent a country weekend together. Shortly afterwards Lawrence and Frieda returned to Europe where they urged Mansfield and Murry to join them. This offer was declined, but on two later occasions, in 1914 and 1916, Mansfield and Murry spent several months living in the English countryside as neighbours of the Lawrences.

Mansfield's friendship with Lawrence had no discernible influence on her writing, and she eventually became exasperated by his preoccupation with sex and his constant quarrels with Frieda. Lawrence, on the other hand, put his association with Mansfield to extensive literary use. In his novel, Women in Love (1920), the figures of Gudrun and Gerald are based on Mansfield and Murry. In The Rainbow (1915), Lawrence's depiction of a sexual relationship between a younger and older woman bears a strong resemblance to Mansfield's experiences with Edith Bendall, which suggests that it may have been drawn from his conversations with Mansfield.

After the collapse of the Blue Review, Mansfield and Murry gave up the cottage in the country and moved from the small apartment in Chancery Lane, which had served as the offices for Rhythm and the Blue Review, to a larger apartment in Baron's Court. Mansfield was now free to write, but she did not find the atmosphere conducive to creativity and her efforts met with little success. Murry also had literary aspirations, and in December he and Mansfield moved to an apartment at 31 rue de Tournon, on the Parisian Left Bank, where they hoped it would be easier to focus on their writing. 
Murry believed that his earnings as a freelance journalist would be sufficient to support both of them in Paris-although he was still making quarterly payments towards the outstanding debts of Rhythm. In February 1914, however, he was declared bankrupt and was obliged to return to London to take up regular employment as an art critic with the Westminster Gazette. Mansfield remained in Paris where a friend of Murry's, the novelist Francis Carco, helped her to sell their furniture to pay the fine for breaking the lease.

During her time in Paris, Mansfield wrote only one story called 'Something Childish But Very Natural'. It describes a young couple, named Henry and Edna, who find a dream cottage in the English countryside and reflects some of Mansfield's own longings for a more settled domestic life. The slender narrative is overburdened with detail, but the working of Henry's inner consciousness is captured with skill. The climax, in the final two sentences, is an early example of Mansfield's later practice of bringing her stories to an abrupt close without any formal conclusion.

A few weeks after her return to London, Mansfield moved with Murry into dreary lodgings in Fulham. The Parisian episode had left them short of money and they suffered from frequent bouts of ill health. During this unhappy and unproductive period, Lawrence and Frieda came to dinner and Mansfield's feelings of frustration were further exacerbated by the contrast in their fortunes. Since the publication of Sons and Lovers in 1913, Lawrence's reputation had soared and he had been offered a $£ 300$ advance for his next novel. Furthermore, Frieda's previous marriage had been dissolved and, unlike Mansfield and Murry, they were free to marry. After Lawrence and Frieda had left, Mansfield and Murry had a violent argument which led to their moving, a few days later, to more cheerful accommodation in Chelsea. From there, on 13 July, they set off to act as witnesses at the registry office marriage of the Lawrences. A photograph of this occasion shows Mansfield standing beside Lawrence, in a wide-brimmed hat, looking remarkably elegant. The only other witness was an Irish lawyer friend named Gordon Campbell, who later inherited the title of Lord Glenavy. On her wedding day Frieda gave Mansfield the ring from her former marriage, which Mansfield wore until her death.

At midnight on 4 August 1914, Britain entered World War I and for the next four years Mansfield shared, with millions of others, in the deprivations and sufferings of war. Her only brother and some of her closest friends were killed, leaving Mansfield with lasting psychological scars and a conviction that the world - and literature — had been irrevocably changed by the horrors of war.

In October 1914 Mansfield and Murry moved once more to Buckinghamshire where they rented a cottage three miles away from the 
Lawrences. A few weeks later, in the aftermath of a violent quarrel between Lawrence and Frieda, Mansfield met Samuel Koteliansky. Koteliansky was a Russian Jew who for political reasons had emigrated to England from the Ukraine in 1911. He was a regular weekend guest of the Lawrences and became one of Mansfield's closest friends. Initially, however, he was also her ardent admirer and showered her with gifts of chocolates and cigarettes. Murry, meanwhile, was becoming increasingly obsessed with the work of Dostoevsky, whose novels had been recently translated into English. To Mansfield's disgust, he spent many of his evenings in intense, metaphysical discussions with Lawrence and Gordon Campbell from which she felt excluded. Their relationship suffered and as her feelings for Murry cooled, Mansfield embarked on an ardent correspondence with Carco, who was serving in the army in France.

In February 1915 Mansfield set off for Paris. She borrowed the money for the trip from her brother, Leslie, who had recently arrived in England to join a British regiment. In France, Mansfield embarked on a four-day tryst with Carco, which took place in the War Zone behind the French lines and is fictionalised in her story 'An Indiscreet Journey'. But Mansfield's love affair with Carco was short-lived and by 25 February she had returned to Murry in Buckinghamshire. In the meantime, she continued to correspond with Koteliansky, who had enlisted Murry's assistance in a venture to publish works by Russian authors in English translation. This project, to which Mansfield also contributed, gave her an opportunity to study the literary techniques of Russian writers, who had been developing new approaches to fiction for several decades.

During 1914 Mansfield wrote very little. The only complete story by her that survives is a work of uneven quality called 'Brave Love'. In March 1915, however, her desire to write revived and she went to Paris where she completed a story called 'The Little Governess', in which she describes an encounter between a naïve young woman and a lecherous old man. As in much of Mansfield's work at this time, sexual undercurrents play an important role, but she handles them with a far greater subtlety than she does in earlier stories such as 'A Blaze.' She also successfully sustains the viewpoint of the governess by moving the narration seamlessly between an external vantage point and interior monologue.

By far the most significant writing that Mansfield did at this time, however, was the first portion of her story 'The Aloe' (1930), which was later revised and became one of her most celebrated works under the title 'Prelude'. 'The Aloe' marks an important step in the evolution of Mansfield's artistic method and is her longest piece of writing. In it, she distils all that she had learnt through practice and experimentation over the previous years in a sequence 
of twelve atmospheric episodes set in the familiar world of her New Zealand childhood. The story is based on the move made by Mansfield, portrayed as 'Kezia', at the age of four and a half, from her first home in Wellington to her family's new house in the countryside. The mysterious central image is provided by an aloe tree, which seems to preside over the fate of the household and only flowers once in a hundred years. As the story unfolds through the consciousness of the characters, the presence of the author is barely discernible. The personalities of the characters are not described, but rather 'revealed' through minutely observed details of their appearance and behaviour - or by their own voices. There is little plot and only the minimum of external action. Instead, the focus is on the subtleties of human relationships and the inner lives of the characters-who are clearly recognisable as the members of the Beauchamp family. Many of the technical innovations in 'The Aloe' are Mansfield's own, which she described to Dorothy Brett in October 1917 as 'more or less my own invention.'1 The approach was so radical that Mansfield felt obliged to warn Murry: 'I expect you will think I am dotty when you read it . . . Its queer stuff.' 2 In May, after a further burst of writing in Paris, Mansfield laid 'The Aloe' aside-believing it to be completed. The following year, however, she rediscovered the manuscript and began reworking it in a lengthy process that was not finalised until 1917.

In June 1915 Mansfield and Murry moved to a comfortable house, with a garden, at 5 Acacia Road in St John's Wood. Their financial situation had improved since Murry's recent employment as a reviewer for the Times Literary Supplement, and Mansfield had also received an increase in her allowance from her father. In August, Leslie came to stay at Acacia Road for his last leave before leaving for France. He and Mansfield spent many hours sharing their memories of home and shortly after he left, Mansfield wrote a vivid evocation of her childhood, in which the turbulent feelings of an adolescent girl are mirrored by the wildness of the Wellington wind. This story appeared in October 1915 as 'Autumns II' in a short-lived magazine founded by Murry and Lawrence called Signature, but it was later renamed 'The Wind Blows'.

On 7 October 1915 Leslie was killed in France by a grenade which exploded in his hand. Mansfield was devastated and remained in a state of depression for many months afterwards. Acacia Road was so full of memories of Leslie that Mansfield no longer wished to live there, and she and Murry departed for the South of France where they found little of the warmth and

\footnotetext{
${ }^{1}$ Murry, The Letters of Katherine Mansfield, Vol 1, p. 84. (Letter to the Hon. Dorothy Brett, Thur., Oct. 7, 1917.)

${ }^{2}$ O'Sullivan and Scott, The Collected Letters of Katherine Mansfield, Vol.1, p.168. (Letter to Murry of 25 March 1915.)
} 
consolation that they had anticipated. Relations between them once again became strained and in early December Murry returned to England leaving Mansfield in a hotel in the small seaside town of Bandol. He spent Christmas at Garsington Manor in Oxfordshire as the guest of Lady Ottoline Morrell, who had gathered around her a brilliant circle of writers and intellectuals, which included Aldous Huxley, Bertrand Russell, and Lytton Strachey. Lonely and unhappy in Bandol, Mansfield bombarded Murry with letters. On New Year's Day 1916 he rejoined her and together they moved to a small house called the Villa Pauline where, for three and a half months, they enjoyed one of their few periods of complete harmony.

Murry at once set to work on a long-planned book on Dostoevsky, but Mansfield, who was still struggling with depression, abandoned any attempts at writing and turned her attention to the novels of Dostoevsky. The observations that she makes on his methods in her journal reveal the acuteness of her mind and her new appreciation of human suffering. There is also a lengthy entry-indicating the precariousness of her mental state-in which she records an extraordinary 'vision' of her brother. From the pain of bereavement, Mansfield forged a new literary philosophy which she expresses in her journal as follows:

Now, really, what is it that I do want to write? . . never has my desire been so ardent. Only the form that I would chooses has changed entirely. . . . The people who lived or whom I wished to bring into my stories don't interest me any more. The plots of my stories leave me perfectly cold. . . . Now-now I want to write recollections of my own country. . . . Oh, I want for one moment to make our undiscovered country leap into the eyes of the Old World. ${ }^{3}$

She links this change of direction specifically to what she perceives as a debt of love both to her birthplace, New Zealand, and to her dead brother. Shortly afterwards she came across the manuscript of 'The Aloe' lying among her papers. In subject matter and outline, it corresponded perfectly to her new literary philosophy, and she spent the remainder of her time at the Villa Pauline reworking the text.

Since January, Lawrence had been writing to Mansfield and Murry in an attempt to persuade them to join him and Frieda in Cornwall. They eventually agreed, and in April 1916 they left the Villa Pauline and moved, with some misgivings, into an empty cottage next to the Lawrences. Mansfield found that living on close quarters with the Lawrences in Cornwall was even more

\footnotetext{
${ }^{3}$ John Middleton Murry, ed., The Journal of Katherine Mansfield, Def. Ed. (London: Constable and Co Ltd., 1967), pp. 93-94.
} 
difficult than living with them in Buckinghamshire. Her hatred of the stony countryside and the quarrels between Lawrence and Frieda disrupted her creative flow. She wrote nothing and the new-found harmony of her relationship with Murry foundered. In June she and Murry moved to another cottage, thirty miles from the Lawrences, but she was still unhappy and sought to console herself by visiting London and Garsington without Murry.

In September, Mansfield and Murry returned to London where Murry had been appointed to a department of the War Office as a translator and reviewer of the foreign press. Murry and Lawrence had quarrelled in Cornwall and the friendship between the two couples cooled. At the same time an unexplained estrangement occurred between Mansfield and Koteliansky. It lasted for the next two years and was probably related to the quarrel with Lawrence. Meanwhile, Mansfield and Murry were becoming increasingly involved with Ottoline Morrell and her circle at Garsington. They took up lodgings on the ground floor of a house in Bloomsbury, in which two young painters, Dorothy Brett and Dora Carrington, whom they had met at Garsington, also lived. Murry started writing affectionate notes to Ottoline, while Mansfield carried on a mild flirtation with her long-term admirer, Bertrand Russell. In November, Lytton Strachey arranged the first meeting between Mansfield and Virginia Woolf. Over Christmas at Garsington, Mansfield wrote a skit on Chekhov's Cherry Orchard (1903) called The Laurels, which was acted by the guests on Boxing Day to widespread acclaim.

The house in Bloomsbury did not offer Mansfield the peace she needed for her writing, and in February she moved, without Murry, to a one-roomed studio in Chelsea. Murry lodged nearby and came regularly for dinner. Ida Baker, who had recently returned from a two -year visit to Rhodesia, was also a frequent guest, and eventually gave up her own apartment to sleep behind a curtain in the studio. Mansfield had re-established contact with Orage, and over the next ten months she contributed a number of pieces to the New Age, including six 'fragments' and five comic dialogues in which she displays her keen ear for spoken language and her ready wit. The New Age also published three more stories: a brilliant and satirical portrait of Bowden called ' $\mathrm{Mr}$ Reginald Peacock's Day'; a slight love story called 'An Album Leaf' (later renamed 'Feuille d'Album'. and a light-hearted parody on a Russian theme called 'A Dill Pickle'.

During this productive period, Mansfield received a flattering approach for a story from Virginia and Leonard Woolf, who had recently set up the Hogarth Press. Mansfield offered them 'The Aloe', which she further revised, reducing it from 26,000 to 17,000 words and renaming it 'Prelude'. 'Prelude' retains the structure and most of the main characters of 'The Aloe', but several lengthy digressions have been removed. Similarly, superfluous descriptions have 
been pruned and the dialogue has been cut back to increase its dramatic effect. Occasionally, a vivid new detail has been inserted to heighten the atmosphere. The only figure to undergo extensive revision is that of Mansfield's mother, depicted as Linda Burnell, who becomes more elusive as a character and acquires a greater detachment. When the first edition of 'Prelude' was published in 1918, Virginia Woolf had to defend it from the criticisms of her family and friends. It did not reach a wider public, or receive the critical attention it merited, until 1920, when it was included in Mansfield's second collection of short stories, Bliss. In an enthusiastic review of Bliss in the New Statesman of 15 January 1921, a half column was devoted to 'Prelude', which is identified as one of the finest stories in the collection

Although Mansfield and Woolf had much in common as writers, they did not immediately warm to each other. Woolf was shocked when Mansfield unwisely regaled her with some of her youthful sexual escapades and took some time to appreciate the quality of her mind. Mansfield on the other hand recognised Woolf's talent at an early stage, and both women enjoyed the professional interest of their conversations. In August 1917 Mansfield wrote to Woolf in terms that openly acknowledged their shared literary objectives: 'It was good to have time to talk to you. We have got the same job, Virginia and it is really very curious and thrilling that we should both, quite apart from each other, be after so very nearly the same thing. We are you know; there's no denying it.' 4 In 1919, however, she alienated Woolf by writing a critical review of her novel, Night and Day (1919). After the publication of Mansfield's collection, Bliss, in 1920, Woolf overcame her professional jealousy and wrote to congratulate her. Mansfield replied, but their friendship lapsed when she failed to respond to a second letter.

At the end of 1917 Mansfield became seriously ill after catching a chill at Garsington. On her return to London she was diagnosed with tuberculosis, with which she appeared to have been infected for some time. At a time when the only known cure for tuberculosis was rest and sunshine, all Mansfield's doctor could do was recommend that she went abroad to avoid the English winter. On 7 January 1918, therefore, she set off alone for Bandol which she found altered very much for the worse by four years of war. The hotel was half-deserted and bitterly cold and Mansfield soon became deeply depressed. Her feelings of loneliness and despair are poured out in a stream of letters to Murry and prompted the writing of one of her darkest stories, 'Je ne Parle pas Francais' (1920).

\footnotetext{
${ }^{4}$ O'Sullivan and Scott, The Collected Letters of Katherine Mansfield, Vol. 1, p. 327. (Letter to Virginia Woolf of c. 23 August 1917.)
} 
Like most of Mansfield's stories, the subject matter of 'Je ne Parle pas Francais' is drawn from personal experience. The story unfolds through the first person narration of a Frenchman named Raoul Duquette, for whom Carco is the model. Its central figures are Mansfield, portrayed as the fragile and innocent 'Mouse', and Murry, as her spineless fiancé, Dick Harmon, who abandons her in Paris. Mansfield wrote 'Je ne Parle pas Francais' in a mood of intense pessimism and she describes it in a letter to Murry as her "cry against corruption'.5 The sexually ambivalent figure of Duquette symbolises amorality, and Mansfield uses his inner reflections to reveal not only his depravity, but also her own disgust with contemporary society. Her depiction of Murry is equally unflattering and reflects her feeling that he had abandoned her at one of the most difficult times in her life. Although Murry was very hurt by the story, he immediately recognised its force and suggested that its inspiration might have been Dostoevsky's 'Notes from the Underground' (1864) - a link which is generally accepted.

Murry's wartime work prevented him from leaving England, but within a few weeks Ida was able to join Mansfield at Bandol. By now, however, Mansfield was absorbed in her writing and resented the intrusion. Nevertheless, Ida's arrival was timely, for within a few days Mansfield suffered her first lung haemorrhage. She was badly shaken and recorded her emotions in her notebook: 'Oh, yes, of course I am frightened . . . I don't want to find this is real consumption, perhaps its going to gallop—who knows-and I shan't have my work written, Thats what matters. How unbearable it would be to die, leave "scraps", "bits", nothing real finished. ${ }^{6}$

'Je ne Parle pas Francais' was published as a single edition in January 1920 by the Heron Press, which was set up by Murry and his brother, Richard. In April it received a favourable review in the Athenaeum, in which Mansfield is described as 'The Story-Writing Genius'.7 She completed two further stories at Bandol, 'Sun and Moon', in which the adult world is seen from the viewpoint of a little boy, and 'Bliss'. In 'Bliss', which first appeared in August 1918 in the English Review, Mansfield explores the feelings of a young, married woman named Bertha Young, who discovers, in course of an elegant, London dinner party that her husband has been unfaithful to her. Erotic undercurrents flow between Bertha and a beautiful, female guest, and the story gains a further, symbolic dimension from the image of a blossoming pear tree. Despite its obvious cleverness, however, 'Bliss' is not as highly regarded as 'Prelude', or many of the stories that followed it. Contemporary

${ }^{5}$ O'Sullivan and Scott, The Collected Letters of Katherine Mansfield, Vol. 2, p. 54. (Letter to Murry of 3 Feb 1918.)

${ }^{6}$ Margaret Scott, The Katherine Mansfield Notebooks, Vol. 2, p. 125.

${ }^{7}$ J. W. N. Sullivan, 'The Story-Writing Genius', Athenaeum, 2 April 1920, p. 447.

Kōtare 7, no. 1 (2007), pp.63-98. 
reviewers praised Mansfield's grasp of psychology, but, as Sylvia Berkman points out in her critical study of Mansfield's work, the reader is often alienated by the overwrought and gushing tone of Bertha's interior monologue and by the superficiality of the characters.

Mansfield was anxious to leave the isolation of Bandol at the earliest opportunity, but in wartime France she had difficulty in obtaining the necessary travel permit. Finally in March she and Ida set off for England by train. It was a nightmare journey and in Paris they were forced, by the German bombardment, to interrupt their journey. They remained trapped there for three weeks with German shells falling every eighteen minutes. Mansfield spent many hours nightly sheltering in the cellars of her hotel, and by the time she reached England her health had deteriorated still further. She had lost over a stone in weight and Murry was shocked by the change in her appearance. When Mansfield visited her London doctor, he recommended that she enter a sanatorium, but Mansfield rejected his suggestion and decided to attempt a cure at home.

In late April, Mansfield's divorce from Bowden was finalised, and on 3 May 1918 she and Murry were married at the same South Kensington Register Officer at which the Lawrences had married four years earlier. Their witnesses were Murry's long standing friend, the Scottish painter, John Duncan Fergusson, and Dorothy Brett. Afterwards they planned a small party, but the occasion was clouded by Mansfield's ill health and within two weeks of their marriage, she and Murry were once again separated. Mansfield's efforts to cure herself at home had met with little success and she agreed, reluctantly, to convalesce in a comfortable hotel in Cornwall where she could benefit from sea air and country food. Murry, meanwhile, had leased a house for them in Hampstead, which was considered a more healthy location than central London. At the end of August he and Mansfield moved to their new home at 2 Portland Villas where they employed three domestic staff and Ida as a housekeeper.

Soon after she moved to Portland Villas, Mansfield re-established contact with Koteliansky. Their friendship revived and by November Mansfield had taken on Murry's earlier task of polishing and improving Koteliansky's translations from Russian. Over the next four years, Mansfield assisted Koteliansky with at least six works of Russian translation. The most significant of these was a collection of Chekhov's letters, which appeared in 1919 in instalments in the Athenaeum. Chekhov's letters gave Mansfield a greater understanding of his personal philosophy and further increased her admiration for him as a writer and as an individual.

During October, Mansfield visited two lung specialists both of whom insisted that her only chance of recovery lay in entering a sanatorium. She 
preferred, however, to follow the advice of her new doctor, Victor Sorapure, with whom she had established a warm friendship. Sorapure sympathised with Mansfield's view that a protracted stay in a sanatorium would her do more harm than good, because the strict regime would hinder her writing. In addition to the sufferings of tuberculosis, she was continuing to experience agonising pains in her joints. Woolf came to tea in November and describes Mansfield in her diary as follows: 'Katherine was up, but husky and feeble, crawling about the room like an old woman.' 8 Shortly before Christmas, Mansfield learnt from Sorapure that the pains, which for the past eight years she had attributed to rheumatism, were caused by gonorrhoea. For the next two months she submitted to a course of injections, which brought on regular bouts of high fever, but did little to cure her.

On 11 November 1918, World War I ended. Mansfield and Murry joined in the universal rejoicing and celebrated Christmas in high spirits with a group of their closest friends. Within the War Office, Murry had risen to the post of Chief Censor, but his editorial talents had been noticed by London's literary establishment, and in February 1919 he was appointed as editor of the prestigious weekly journal, the Athenaeum. His new position brought with it a salary of $£ 800$ a year and offered Mansfield new opportunities for employment. She was invited by Murry to write the reviews of the novels, and over the next twenty months she wrote more than one hundred reviews, which did much to establish her reputation as a critic. After Mansfield's death Murry collected the reviews and published them in 1930 under the title of Novels and Novelists.

Throughout 1919 Mansfield was fully occupied with writing reviews for the Athenaeum and translation work with Koteliansky. In June she expresses her enthusiasm for Chekhov's letters in a letter to Koteliansky: 'I do my very best always with these wonderful letters . . . May Tchekov live for ever.' 9 In August, in another letter to Koteliansky, she is even more explicit: 'Tchekhov has said the last word that has been said, so far, and more than that he has given us a sign of the way we should go . . . My God, if I am sitting on the back bench, A. T. is my master.' 10 The only story that dates from this period is a delicate study of an unsatisfactory meeting between two friends, called 'Psychology'.

Mansfield's mother had died in August 1918, and in August 1919 Harold arrived in London as a widower. He called on Mansfield and Murry in

\footnotetext{
${ }^{8}$ Anne Olivier Bell, ed., The Diary of Virginia Woolf, Vol. 1 (New York and London: Harcourt Brace Jovanovich, 1979), p. 216. (Entry for 9 Nov 1918.)

${ }^{9}$ O'Sullivan and Scott, The Collected Letters of Katherine Mansfield, Vol. 2, p. 324. (Letter to Koteliansky of 6 June 1919.)

${ }^{10}$ Ibid., p. 345. (Letter to Koteliansky of early August 1919.)
} 
Hampstead. Mansfield greatly enjoyed the occasion and hoped that the meeting might prompt her father to make an increase in her allowance to help with her soaring medical expenses. Murry, however, was barely civil to his father-in-law and no increase was forthcoming. Mansfield's continuing illhealth was adversely affecting her marriage. She and Murry slept in separate rooms and their moments of intimacy became increasingly rare.

In September, Mansfield set out for San Remo on the Italian Riviera where she and Ida planned to spend the winter, but within a few days of her arrival Mansfield was asked to leave the hotel in which she, Murry and Ida were staying. At that time the Italians regarded tuberculosis as a notifiable disease, and Mansfield's condition was unmistakable. The manager, however, then offered to lease her a small villa on an isolated hillside, which she gratefully accepted. Once Mansfield and Ida were installed, Murry returned to London. At first the villa seemed ideal, but it was unheated and quite unsuitable for winter habitation. In the increasing cold and discomfort Mansfield's health and temper deteriorated. She quarrelled violently with Ida and, as she struggled with suicldal depression and incipient pneumonia, she wrote a stream of nearhysterical letters to Murry.

At Christmas, Murry spent a few days at the villa. In the aftermath of his visit Mansfield felt calmer and more able to write. On Sunday 11 January 1920 she sat down and wrote a story, which she finished that same evening. It is the portrayal of a fretful invalid and her long-suffering husband, which Mansfield called 'The Man Without a Temperament'. Her subject matter is clearly drawn from her own situation, but in 'The Man Without a Temperament' she achieves a new objectivity that gives the story a universal dimension. In 1921 it was described in the New Statesman by Desmond MacCarthy as being, (with 'Prelude'), the finest story in Bliss. At this stage in her life, Mansfield was striving for greater perfection in her work, driven by the fear that she might die before she had achieved her full literary potential. Inspired by Chekhov, she was also trying to overcome her own personal shortcomings in the belief that only those of the highest moral calibre could become great writers. The greater objectivity and compassion that begins to appear in Mansfield's stories at this time is a reflection of her new beliefs-as is her belated recognition of Ida 's devoted friendship.

Shortly after completing 'The Man Without a Temperament', Mansfield accepted the invitation of a wealthy cousin named Connie Beauchamp to join her and a friend, Jinnie Fullerton, at their luxurious villa in Menton. Mansfield was so ill that she was obliged to spend her first three weeks in Menton in an expensive nursing home where her unhappiness was compounded by a vicious letter from Lawrence. Unaware that he also had tuberculosis, he 
wrote: 'I loathe you. You revolt me stewing in your consumption.'11 This outburst was quite unprovoked, but like Mansfield, Lawrence was susceptible to violent mood swings and fits of tubercular rage. To add to her troubles, Mansfield was worried about the cost of the nursing home, but the financial situation was eased when Murry negotiated an advance of $£ 40$ from the publisher, Constable, for a new collection of her stories.

Once Mansfield moved to the Villa Flora, she became happier. After years of financial hardship she basked in the luxury of the villa, which recalled many of the comforts of her childhood home. Connie Beauchamp and Jinnie Fullerton were devout Roman Catholics and tried their utmost to convert Mansfield to their faith. In March she told Ida, who had taken a job in the neighbourhood, that she was considering becoming a Catholic, but this notion was soon rejected. After three months in Menton, Mansfield returned to London where she continued to produce a steady flow of reviews for the Athenaeum, in which three of her short stories also appeared. In two of them, 'Revelations' and 'The Escape', Mansfield reveals her determination to write with greater honesty and integrity by ruthlessly exposing the weaknesses of the central, female figure, whose faults are very similar to her own.

By mid-August, Mansfield was again seriously ill. She describes her condition in her notebook: "I cough and cough and at each breath a dragging boiling bubbling sound is heard. I feel that my whole chest is boiling. I sip water. spit, sip, spit. I feel I must break my heart. And I can't expand my chest-it's as though the chest had collapsed. Life is-getting a new breath. Nothing else counts.' 12 In September, Mansfield returned to Menton where she and Ida took up residence in the Villa Isola Bella. The villa was rented from Jinnie Fullerton, who was living close by with Connie Beauchamp, and it came with an excellent French cook called Marie. At Isola Bella, Mansfield at last found herself in comfortable surroundings that were ideally suited for writing. A stream of stories followed: 'The Young Girl', 'The Singing Lesson', 'The Stranger', 'Miss Brill', 'Poison', 'The Lady's Maid', 'The Daughters of the Late Colonel', and 'Life of Ma Parker'.

Each one is a study of an aspect of female experience. In 'The Young Girl', Mansfield explores the expectancy and optimism of youth; in 'Miss Brill', 'The Lady's Maid', and 'Life of Ma Parker' she portrays female poverty and loneliness; in 'The Singing Lesson' she examines a broken engagement; and in 'The Stranger' she describes the estrangement of a married couple after many months of separation. The most celebrated story of this group, however,

\footnotetext{
${ }^{11}$ O'Sullivan and Scott, The Collected Letters of Katherine Mansfield, Vol. 3, p. 209. (Quoted in a letter to Murry of 7 Feb 1920.)

${ }^{12}$ Scott, The Katherine Mansfield Notebooks, Vol. 2, p. 219.
} 
is 'The Daughters of the Late Colonel', which is the tale of two sisters whose lives have been overshadowed by their domineering father. The model for the most timid of the sisters, Constantia, is Ida, whose own father was an irascible Indian Army doctor. The story is built up from a series of scenes in which the sisters' world is revealed through their relationships with different people. The narration alternates between flashbacks to the past and scenes in the present. In early 1921 Mansfield described her approach to her brother-in-law, Richard Murry, as 'the outcome of the Prelude method-it just unfolds and opens. ${ }^{, 13}$ When this story was published in May 1921 in the London Mercury, it elicited a flattering comparison with Chekhov from the Russophile, William Gerhardie: 'I think it is . . . of quite amazing beauty. . . I don't remember reading anything so intolerably real—stifling-since "The Three Sisters".,14

By now Mansfield was approaching the height of her literary powers, and the Isola Bella stories demonstrate not only the maturing of her creative abilities, but also her mastery of a wide range of literary techniques acquired through an intense dedication to craftsmanship. In a letter to Richard Murry, dated 17 January 1921, Mansfield voices her commitment: 'It's a very queer thing how craft comes into writing. I mean down to details. Par exemple. In 'Miss Brill' I chose not only the length of every sentence, but even the sound of every sentence-I chose the rise and fall of every paragraph to fit her-and to fit her on that day at that very moment. After l'd written it I read it aloudnumbers of times- just as one would play over a musical composition, trying to get it nearer and nearer to the expression of Miss Brill-until it fitted her. ${ }^{15}$

Much of the success of Mansfield's characterisation rests on the authenticity of the language in which her characters speak and think. The vocabulary and diction of the downtrodden cleaning woman, Ma Parker, is reproduced with astonishing fidelity and mirrors the limitations of her horizons. Mansfield also uses this skill to delineate human relationships-such as the gulf that exists between Ma Parker and the 'literary gentleman' who employs her. His incomprehension of Ma Parker's sufferings is encapsulated in a few short lines of condescending dialogue. Another of Mansfield's frequently used devices is her practice of associating emotion with an inanimate object to convey feelings. In 'Miss Brill', for example, the old woman's loneliness is emphasised by the conversations which she holds with her fur tippet. In 'The Young Girl' Mansfield heightens the mood through the visualisation, in minute

\footnotetext{
${ }^{13}$ O'Sullivan and Scott, The Collected Letters of Katherine Mansfield, Vol. 4, p. 156. (Letter to Richard Murry of 1 Jan 1921.)

${ }^{14}$ Letter from William Gerhardie to Katherine Mansfield of 17 June 1921, Mansfield Papers, MS-Papers-4004-37, ATL.

${ }^{15}$ O'Sullivan and Scott, The Collected Letters of Katherine Mansfield, Vol. 4, p. 165. (Letter to Richard Murry of 17 Jan 1921.)
} 
and vivid detail, of sensuous images of flowers and food, which echo the sensuous beauty of the youthful heroine.

Only 'Poison' falls short of Mansfield's new artistic standards as she vents her feelings of jealousy towards Princess Bibesco, with whom Murry had been carrying on a flirtation. During November and December 1920 the almost daily correspondence between Mansfield and Murry grew increasingly acrimonious. Overtly, the cause was an unflattering photograph of Mansfield, which had appeared with Murry's authorisation, in a weekly paper called the Sphere, but the underlying reasons were more probably her ill-health and her suspicion that Murry's affections were straying. On 8 December their quarrel culminated in Mansfield's resignation as a reviewer for the Athenaeum. At Christmas, Murry came out to Isola Bella where relations between him and Mansfield were further strained by the stream of letters that arrived from Princess Bibesco. During Murry's visit, however, a reconciliation took place, and he decided to give up his editorship of the Athenaeum so that he could join Mansfield at Menton.

Throughout this difficult period in her personal life, Mansfield's reputation as a writer was growing. On 2 December 1920 her second collection, Bliss, was published. Although it did not contain her most recent stories, it included 'Prelude', 'Je ne Parle pas Français', and 'The Man Without a Temperament' and was widely and favourably reviewed. In February 1921 an American issue was brought out by Knopf. In his review of 11 May in the Freeman, Conrad Aiken made the following comments: 'Miss Mansfield is brilliant-she has, more conspicuously than any contemporary writer of fiction one calls to mind, a fine, an infinitely inquisitive sensibility'. Reviewers on both sides of the Atlantic remarked on the affinity between Mansfield and Chekhov, but Aiken was careful to stress the individuality of her talent: 'One has not read a page of Miss Mansfield's book before one has said "Chekhov": but one has not read two pages before Chekhov is forgotten. ${ }^{16}$

Mansfield was undoubtedly gratified by this public recognition of her abilities, but in her declining state of health, she was becoming increasingly preoccupied with spiritual matters and the desire to make amends for the shortcomings of her youth. In November, after months of silence, she initiated a correspondence with her father and asked his forgiveness for her past behaviour. In February 1921 she wrote a conciliatory letter to Koteliansky, with whom she had once again quarrelled, but he did not reply and it was many months before their friendship was re-established. She also wrote warmly to Orage, thanking him for his guidance to her as a young writer.

\footnotetext{
16 'The Short Story as Poetry', Conrad Aiken, Freeman, 11 May 1921, pp 210-211.
} 
In March 1921 Ida returned to London to pack up the house in Hampstead. Mansfield missed her help and found Murry's presence more of an irritation than a support. She wrote no further stories, and in May she decided to move with Ida to Switzerland where she hoped to find a cure. Murry, meanwhile returned to England where he was to deliver a series of lectures at Oxford. For much of May, Mansfield stayed in a hotel in Montreux, where she tried to disguise her tubercular condition by claiming to have a weak heart. In June she moved to the little town of Sierre to place herself under the supervision of a specialist named Dr. Spahlinger. There she was rejoined by Murry, and at the end of June they moved to a house in the pine forests high above Sierre called Chalet des Sapins. Ida lodged in the village and took a job in a nearby clinic.

At Chalet des Sapins, Mansfield and Murry enjoyed another of their rare periods of harmony — not unlike their stay at the Villa Pauline in early 1916. The peace and beauty of the surroundings contributed to their happiness, and Mansfield experienced a lengthy burst of creativity. Despite the success of Bliss, however, she still had financial concerns. Her medical bills were mounting, and to meet them she accepted a commission from the editor of the Sphere for six stories at ten guineas each. These stories were written under pressure and not all of them are Mansfield's best work. In two of them, 'An Ideal Family' and 'Marriage à la Mode', the subject matter has been taken from Chekhov ('Ma Parker' also has a Chekhovian counterpart), but among the six are also two of Mansfield's finest stories in which she reverts once more for inspiration to her New Zealand childhood. 'Her First Ball' describes the emotions of a young girl who encounters a cynical, older man at her first ball, while 'The Voyage' gives a flawless account, from the perspective of a child, of the sea voyage between the North and South islands of New Zealand.

Mansfield's notebooks reveal that she was often dissatisfied with her commercially-driven writing for the Sphere. At the same time, a new story was taking shape in her mind that was a far truer reflection of her talents and is considered by many critics to be her masterpiece. On 10 September, after nine hours of writing, Mansfield completed a continuation of 'Prelude', which she called 'At the Bay'. The cast of characters is drawn from Mansfield's family circle and includes many of the same figures as 'Prelude'. The story is in twelve episodes, each of which revolves around a different character. It opens with a lyrical description of the native bush that surrounded the Beauchamp's summer cottage in Wellington Harbour and goes on to trace the activities of the different members of the household and their neighbours in the course of a summer day. As the story progresses, the viewpoint shifts from person to person to create a picture of their widely differing personalities 
and the complexities of their relationships. Mansfield excels in her portrayal of the children, and their game of cards in the wash-house is one of the most celebrated scenes in the story.

In 'At the Bay', Mansfield returns to many of the techniques of 'Prelude', but she imposes a far more rigorous temporal framework. The narrative is compressed within one day rather than three and is punctuated by fluctuations of mood that reflect the changing atmosphere of a seaside environment as it passes from the cool of dawn, through the heat of midday, to the warmth of a summer night. With 'Prelude' and 'Je ne Parle pas Français', 'At the Bay' is among Mansfield's longest works and is one of the few in which she portrays a whole community.

'At the Bay' was favourably received both when it first appeared in the London Mercury in January 1922 and on its inclusion a month later in Mansfield's third collection, The Garden Party (1922). In an overview of Mansfield's work, which was published in the Spectator Literary Supplement shortly after her death in 1923, Martin Armstrong commented as follows:

Her chief characteristic is an exquisite sensibility. . . . Her stories fall roughly into two classes. In one we are shown a personality reacting more or less acutely to a moment of psychological crisis or revealed for a moment in its own special psychological atmosphere .... And there is the other class which presents, as it were, two or three yards out of a long strip of unimportant events in the life of an unimportant family-stories such as 'Prelude' and 'At the Bay', with no beginning, no middle, and no end, which nevertheless are such complete and exquisitely formed works of art because the writer's sensibility acts upon the whole as a flux and melts it into a single experience . . . . ${ }^{17}$

From September 1921 to January 1922 was one of the most productive periods of Mansfield's life during which she completed 'At the Bay' and wrote eight other stories-although four of these were unfinished. Two of her bestloved New Zealand stories, 'The Garden Party' (after which her third collection was named) and 'The Doll's House', date from this time. 'The Garden Party' is set in Wellington at the luxurious house occupied by her parents from 1898 to1907 and revolves around the theme of her family's reactions to the death of a workman on the day of a garden party. Through a series of perfectly executed scenes, Mansfield skilfully contrasts the frivolity of the preparations for the party with the bewilderment of a child confronting death for the first time. In 'The Doll's House', Mansfield reverts to the Beauchamp's earlier home in Karori and once again displays her outstanding ability to depict the

\footnotetext{
${ }^{17}$ Martin Armstrong, Spectator Literary Supplement, 10 Feb 1923, p. 211.
} 
speech and behaviour of children. Like 'The Garden Party', this story contains a social message, but Mansfield makes her point obliquely by using the gift of a doll's house to highlight the inequalities of the society in which she grew up. A third story, 'A Cup of Tea', in which Mansfield describes a spoilt young woman who invites a beggar girl to tea, can also be read as social commentary, but Mansfield's lightness of touch ensures that none of her stories lapses into crude didacticism.

Of her four unfinished stories, 'The Doves' Nest' (which was used as the title to her fourth and posthumous collection) and 'A Married Man's Story' are the most interesting. The lively tone of 'The Doves' Nest', with its typically Mansfieldian cast of a household of women, echoes much of her earlier work. 'A Married Man's Story', in contrast, is written in a sombre style, through a first person male narrator, for whom the only counterpart in her previous work is the very different figure of Raoul Duquette in 'Je ne Parle pas Français.'

Mansfield's health was continuing to deteriorate. In October she wrote another letter to Koteliansky asking for information about a Russian doctor named Ivan Manoukhin, who claimed to have discovered a new cure for tuberculosis. On this occasion Koteliansky replied and their friendship revived. Murry was sceptical about Manoukhin's methods, but Mansfield was convinced that he could help her and made plans to visit his clinic in Paris. Shortly before her departure Mansfield started to read a book called Cosmic Anatomy or the Structure of the Ego (1921), which Orage had sent Murry to review. Its purported author was $\mathrm{M}$. B. Oxon, the pseudonym of a theosophist contributor to the New Age, but its contents bore a strong resemblance to the semi-mystical teachings of the Russian intellectual, Piotr Ouspensky and his mentor, George Gurdjieff. Mansfield was fascinated by the book, although Murry did not share her enthusiasm, and she struck up a secret correspondence with Orage who had become Ouspensky's ardent disciple.

On 30 January 1922 Mansfield and Ida left Switzerland for Paris, where Mansfield embarked on an expensive and unpleasant course of X-ray treatments with Manoukhin. In early February she wrote a deeply pessimistic story called 'The Fly', which is a chilling commentary on divine indifference and the tragedy of war. Mansfield approaches her theme through the story of a man, known simply as 'the boss', who drowns a fly in a pool of ink. She links the image of the fly to that of her dead brother and uses the struggles of the dying insect as a metaphor for human helplessness. The all-powerful figure of 'the boss' contains elements of Mansfield's father and God. 'The Fly' first appeared in the Nation and Athenaeum in March 1922 and was included in 1923 in The Doves' Nest, when reviewers hailed it as 'brilliant'. Its theme, which is open to many different interpretations, has been the subject of lively scholarly debate and the discovery that Chekhov had used very similar 
imagery in his story 'Small Fry' has raised questions on the originality of Mansfield's subject matter.

On 22 February 1922 Mansfield's third collection, The Garden Party, was published. It contained fifteen stories, including seven of those written at Isola Bella, five of those written for the Sphere, and 'At the Bay'. It was an instant success and was reprinted in March, April and May. Reviews appeared in many of Britain's major newspapers and periodicals, where Mansfield's expanding literary range received favourable comment. In her review for the New Statesman of 18 March 1922, Rebecca West remarked on the poetic qualities of 'At the Bay' and described Mansfield's writing as being 'the conquest of prose by the logic of poetry'. She also commented on Mansfield's sharpened technique, noting that 'her choice of the incident that will completely and economically prove her point is astonishing'. ${ }^{18}$ The first American edition was published in May 1922 and was in its seventh reprint by the end of 1923.

Mansfield received a flood of congratulatory letters, but the literary success towards which she had struggled for so many years no longer seemed important to her. By now her chief preoccupation was her health. After three months of treatment in Paris, Mansfield left with Murry to spend the summer months in Switzerland. In July she wrote her last surviving story-a slight piece called 'The Canary' - as a gift for Dorothy Brett who came to visit her. She quarrelled with Murry, who moved to another hotel, and they continued to live apart when they returned to London in August. Shortly after her arrival in London, Mansfield had a warm reunion with Orage, who encouraged her to attend the lectures of Ouspensky. A few weeks later Orage resigned as editor of the New Age and made arrangements to enter Gurdjieff's recently established community at Fontainebleau. On 2 October, Mansfield left London for Paris, ostensibly for further treatment with Manoukhin, but she was aware of Orage's plans and before her departure, she called on Ouspensky to obtain the address of Gurdjieff.

After two more weeks of treatment with Manoukhin, Mansfield was no better and was suffering alarming side effects from the X-rays, which made her doubt their efficacy. By 14 October, which was her thirty-fourth birthday, Mansfield had all but decided to follow Orage's example and enter Gurdjieff's community. Any remaining doubts were swept away by two members of the community, who visited her that day at her hotel. One of these was a wellestablished London psychiatrist named James Young, who gave a glowing description of life at Gurdjieff's 'Institute for the Harmonious Development of

\footnotetext{
${ }^{18}$ Rebecca West, New Statesman, Vol. 18, No. 466, 18 Mar 1922, p. 678.
} 
Man'. Two days later Mansfield set off, accompanied by Ida, on a preliminary visit to Fontainebleau, where she had her first encounter with Gurdjieff.

Gurdjieff was an exotic figure, whose flamboyant style was in sharp contrast to the serious and scholarly Ouspensky. Despite his Russianised name, he was of Greek Armenian extraction and his teaching was a blend of Eastern and Western philosophies with elements taken from Orthodox Christianity, Islamic Sufism, and Tibetan Buddhism. His community at Fontainebleau had some English adherents, but the majority of its members were Russians, many of whom were refugees from the Russian revolution. Among them were some talented painters, dancers, and composers to whom Mansfield was immediately attracted. When she met Gurdjieff, she asked him if she might join the community. Gurdjieff responded by allotting her a room on the first floor of the chateau in which the Institute was housed. After Mansfield's death Gurdjieff was criticised for subjecting her to the primitive living conditions at the Institute, but since Mansfield was already critically ill when she entered the community, her stay there is not believed to have hastened her death.

Throughout her last months, Mansfield continued to correspond with Murry. On 9 January 1923 he arrived to stay at the Institute to celebrate the Russian New Year. He and Mansfield spent the afternoon and evening together and at about ten o'clock, when a performance of dancing by members of the community had finished, they set off upstairs to bed. Halfway up the stairs Mansfield was overcome by a fit of coughing, which prompted a violent lung haemorrhage. Two of the Institute's doctors rushed to her assistance, but by half past ten she was dead. Three days later, on Friday 12 January, Mansfield's funeral was held in the Protestant Church at Fontainebleau. It was attended by Murry, Ida, two of Mansfield's sisters, and a few English friends. Gurdjieff was also present with some members of the Institute. Afterwards her body was buried at the nearby cemetery of Avon. Murry, however, forgot to pay for the funeral and her remains were removed by the authorities to a plot designated for paupers. When Harold heard of this in 1929, he arranged for her grave to be returned to the main cemetery where her gravestone can be seen to this day.

Mansfield's early death, following so closely on her emergence as one of the most interesting new writers of her generation, provoked an outpouring of sympathetic coverage in the British and US Press. On 18 February 1923 The New York Times Book Review devoted a full page to her life and work entitled 'The Rare Craftsmanship of Katherine Mansfield'. The following extract from the article, in which an attractive photograph of Mansfield featured prominently, reflects contemporary reactions to her death: 'Katherine Mansfield was the greatest exponent of the art of the short story that England 
has yet produced, and was the peer of any short-story writer of our country . . .. Had she lived another ten years, it is likely that her name would be written in the history of English fiction beside the names of George Eliot and Charlotte Brontë.' 19

In her will Mansfield left all her personal papers to Murry with instructions to publish as little as possible. Murry, however, immediately produced a stream of articles and publications drawn from the literary estate of his late wife. The collection, The Doves Nest, appeared in June 1923 and contained twenty-one stories. Fifteen of them were unfinished, but some of Mansfield's best work was also included, such as 'The Doll's House' and 'The Fly'. On 7 July 1923, The Doves' Nest was reviewed in the New Statesman by Raymond Mortimer who did not rank it as highly as Bliss or The Garden Party. Nevertheless, he acknowledged that 'few writers have better described the unorganised flow of thoughts and feelings that continually move through the different layers of human consciousness'. ${ }^{20}$ In November of the same year, Murry produced a volume of Mansfield's poems and in August 1924, he published her fifth collection, Something Childish and Other Stories. As the title suggests, many of the stories in this collection are Mansfield's early work and had previously appeared in periodicals.

In 1927 public interest in Mansfield was further encouraged by the appearance of The Journal of Katherine Mansfield, carefully edited by Murry. This was followed in 1928 by The Letters of Katherine Mansfield in two volumes and by The Aloe and Novels and Novelists in 1930. In 1933 Murry co-authored a biography with Ruth Elvish Mantz entitled The Life of Katherine Mansfield which closes in 1912. In 1939 he produced The Scrapbook of Katherine Mansfield.

As more of her writing was published, Mansfield's admirers proliferated. Translations of her stories appeared in several countries, most notably in France, where the translation of her letters in 1931 and her journal in 1932 gave rise to a cult following. Murry's editorial activities continued until shortly before his death in 1957, culminating in a fuller version of the letters in 1951 entitled Katherine Mansfield's Letters to John Middleton Murry, 1913-1922, and a 'Definitive Edition' of the Journal of Katherine Mansfield in 1954. The image, however, that he projected of a pure-minded and delicate artist was a pale and sanitised version of the real woman. Furthermore, his creation of a 'legend' and the volume of biographical material that he produced distracted critics from serious engagement with Mansfield's work.

19 'The Rare Craftsmanship of Katherine Mansfield' , The New York Times Book Review, 18 Feb 1923, p.7.

${ }^{20}$ Raymond Mortimer, New Statesman, Vol. 21, No. 534, 7 July 1923, pp. 394. 
This shortfall was redressed in 1951 when Sylvia Berkman published Katherine Mansfield: A Critical Study, which still remains the best full-length critical study of Mansfield's work. In her evaluation of Mansfield's contribution to literature, which few scholars have challenged, Berkman states that while occupying a minor, historical position, Mansfield stands with James Joyce at 'the head of the broad stream of development in the modern short story'. ${ }^{21}$ In 1953 Antony Alpers' first book on Mansfield, Katherine Mansfield: A Biography, did much to correct Murry's sugar-coated image and presented her personality with more honesty. This was followed during the 1960's and 1970's by several new approaches to her work, including three full-length critical studies and some substantial articles in literary journals. In 1980 Alpers' earlier biography was superseded by his definitive work, The Life of Katherine Mansfield, and in the years leading up to the 1988 centennial of Mansfield's birth, further works of scholarship and biography were published.

By 1988 dozens of different collections of Mansfield's stories had been published with translations in twenty-eight languages, including large numbers of works in Chinese, French, German, Italian, Japanese, Polish, Russian, and Spanish. The Mansfield Centennial was celebrated internationally with events in Wellington, Chicago, Belgium, France, and Germany and prompted the creation of dramatic adaptations of her work for theatre, film, and television. Between 1982 and 1996 editors Vincent O'Sullivan and Margaret Scott completed four of their five-volume The Collected Letters of Katherine Mansfield, which comprise the fullest and most accurate versions of Mansfield's letters to date. In 1997 Scott produced a meticulously revised version of Mansfield's journal entries in two volumes, entitled The Katherine Mansfield Notebooks.

Like many of her personal relationships, Mansfield's relationship with her homeland has not always been straightforward. For several decades after her death she was classified as an English author whose affiliations lay with the London literary world. Her work had little in common with early New Zealand writing and until the 1950's-with the exception of Arthur Sewell's Katherine Mansfield: A Critical Essay in 1936-she received only scant critical attention in New Zealand. After the publication of Berkman's and Alpers' books, perceptions of Mansfield changed, and the importance of her New Zealand identity became established. Moreover, in 1957 New Zealand scholars were encouraged to take a greater interest in her work by the New Zealand government's purchase of the bulk of her personal papers for the Alexander Turnbull Library in Wellington. Despite her many years as an expatriate,

${ }^{21}$ Sylvia Berkman, Katherine Mansfield: A Critical Study (London: Oxford University Press, 1952), p. 197. 
Mansfield is now universally recognised as a New Zealand writer, whose talent was deeply rooted in New Zealand where she located close to half of her stories.

As an individual Mansfield defies definition. She loved disguise and for much of her life, by her own admission, she concealed her inner self behind a series of 'masks'. Because of her habit of adopting a new persona to suit the company in which she found herself, contemporary assessments of her character differ widely. The same problem arises with her letters in which she shows a different side of herself to each correspondent. Even in her personal notebooks, she remains elusive and her true nature is hard to identify. One of the most astute portraits of Mansfield comes from Leonard Woolf, who met her in 1917 and sums her up as follows: 'By nature, I think, she was gay, cynical, amoral, ribald, witty. When we first knew her, she was extraordinarily amusing. I don't think anyone has ever made me laugh more than she did in those days. ${ }^{22}$

In the face of mortal illness Mansfield's outlook changed dramatically. She bitterly regretted her 'misspent youth' and felt that after so many years of dissimulation, she had all but lost her own identity. Two weeks before her death, she wrote to Murry: 'You see, my love, the question is always: "Who am I ?" . . . . if I were allowed one single cry to God, that cry would be: I want to be real.'23 Her last years were dominated by her struggles, largely for artistic reasons, to acquire greater personal honesty and integrity, and among her most admirable characteristics are the courage and commitment with which she pursued these high ideals. The success of her endeavours is demonstrated by the artistic quality of her mature work, which has ensured her an enduring place at the forefront of twentieth century short fiction.

\section{LINKS}

Mansfield Birthplace

New Zealand Book Council

New Zealand Electronic Text Centre (NZETC)

New Zealand Literature File

Project Gutenberg

$\underline{\text { Wikipedia }}$

\footnotetext{
${ }^{22}$ Leonard Woolf, Beginning Again (New York: Harcourt, Brace and World, 1964), p. 204.

${ }^{23}$ Letter to Murry of 26 December 1922.
} 


\section{Bibliography}

\section{Books}

In a German Pension. London: Stephen Swift, 1911; New York: Knopf, 1926.

Prelude. Richmond, U. K.: Hogarth, 1918. Republished, in expanded original version, as The Aloe. London: Constable, 1930; New York: Knopf, 1930.

Je ne Parle pas Français. Hampstead: Heron, 1919.

Bliss and Other Stories. London: Constable, 1920; New York: Knopf, 1921.

The Garden Party and Other Stories. London: Constable, 1922; New York: Knopf, 1922.

The Doves' Nest and Other Stories. Ed. John Middleton Murry. London: Constable, 1923; New York, Knopf, 1923.

Poems. Ed. Murry. London: Constable, 1923; New York, Knopf, 1924.

Something Childish and Other Stories. Ed. Murry. London: Constable, 1924. Republished as The Little Girl and Other Stories. New York: Knopf, 1924.

Journal of Katherine Mansfield. Ed. Murry. London: Constable, 1927; New York: Knopf, 1927.

Novels and Novelists. Ed. Murry. London: Constable, 1930; New York: Knopf, 1930.

The Scrapbook of Katherine Mansfield. Ed. Murry. London: Constable, 1939; New York: Knopf, 1940.

Journal of Katherine Mansfield. Ed. Murry. London: Constable, 1954.

The Urewera Notebook. Ed. Ian Gordon. Auckland: Oxford University Press, 1978.

Poems of Katherine Mansfield. Ed. Vincent O'Sullivan. Auckland: Oxford University, 1988.

The Candle Fairy: Stories, Fairy Tales and Verse for Children. Ed. Alister Taylor. Auckland: Alister Taylor, 1992.

The Katherine Mansfield Notebooks. Ed. Margaret Scott. 2 volumes. New Zealand: Lincoln University Press and Daphne Brasell, 1997.

\section{Selections ANd Collections}

Stories by Katherine Mansfield. Selected by John Middleton Murry. New York: Knopf, 1930.

The Short Stories of Katherine Mansfield. New York: Knopf, 1937.

Collected Stories of Katherine Mansfield. London: Constable, 1945. Republished as The Complete Stories of Katherine Mansfield. New Zealand: Golden in association with Whitcombe and Tombs, 1974; and as The Collected Stories of Katherine Mansfield. London: Penguin, 1981.

Katherine Mansfield: Selected Stories. Chosen and introduced by Dan M. Davin. London, Melbourne and Wellington: Oxford University, 1953.

Stories by Katherine Mansfield. Selected and introduced by Elizabeth Bowen. New York: Vintage, 1956; London and Glasgow: Collins, 1957.

Undiscovered Country: The New Zealand Stories of Katherine Mansfield. Ed. Ian Gordon. London: Longman, 1974. 
The Aloe, with Prelude. Ed. Vincent O'Sullivan. Wellington: Port Nicholson Press, 1982.

The Stories of Katherine Mansfield. Ed. Antony Alpers. Auckland: Oxford University, 1984.

The Garden Party: Katherine Mansfield's New Zealand Stories. Ed. Michael Gifkins, 1987.

The New Zealand Stories of Katherine Mansfield. Ed. O'Sullivan. Auckland: Oxford University Press, 1997.

Katherine Mansfield's Selected Stories. Ed. O'Sullivan. New York: Norton, 2006.

\section{LETTERS}

The Letters of Katherine Mansfield. Ed. John Middleton Murry. 2 volumes, London: Constable, 1928; 1 volume, New York: Knopf, 1929.

Katherine Mansfield's Letters to John Middleton Murry 1913-1922. Ed. Murry. London: Constable, 1951; New York: Knopf, 1951.

The Letters and Journals of Katherine Mansfield: A Selection. Ed. C. K. Stead. London: Allen Lane, 1977.

The Collected Letters of Katherine Mansfield. Eds. Vincent O'Sullivan and Margaret Scott. 4 volumes. Oxford: Clarendon, 1984, 1987, 1993 and 1996.

Selected Letters. Ed. O'Sullivan. Oxford: Clarendon, 1989.

Letters between Katherine Mansfield and John Middleton Murry. Ed. Cherry Hankin. London: Virago, 1988; New York: New Amsterdam, 1991.

\section{BIBLIOGRAPHY}

Kirkpatrick, B. J. A Bibliography of Katherine Mansfield. Oxford: Clarendon, 1989.

Mantz, Ruth Elvish. The Critical Bibliography of Katherine Mansfield. London: Constable, 1931.

Meyers, Jeffery. Katherine Mansfield: A Bibliography of International Criticism, 19211977. Westwood, Ma : Faxon, 1977. Wattie, Nelson. 'A Bibliography of Katherine Mansfield References 1970-84,' JNZL, 3 (1985): 87-120.

Dowling, David. 'Katherine Mansfield: A Bibliography Including Recent Editions and Criticism.' ANZSC, 2 (1989): 157-69.

\section{BIOGRAPHIES}

Mantz, Ruth Elvish and John Middleton Murry. The Life of Katherine Mansfield. London: Constable, 1933.

John Middleton Murry. Between Two Worlds. London: Cape, 1935.

Alpers, Antony. Katherine Mansfield: A Biography. New York: Knopf, 1953; London, Cape, 1954.

Baker, Ida. Katherine Mansfield: The Memories of L. M. London: M. Joseph, 1971.

O'Sullivan, Vincent. Katherine Mansfield's New Zealand. Auckland: Golden Press, 1974.

Meyers Jeffery. Katherine Mansfield: A Biography. London: Hamish Hamilton, 1978.

Alpers. The Life of Katherine Mansfield. New York: Viking, 1980; London: Cape, 1980.

Tomalin, Claire. Katherine Mansfield: A Secret Life. London and New York: Viking, 1987. 
Boddy, Gillian. Katherine Mansfield: The Woman and the Writer. Ringwood, Vic.: Penguin, 1988.

Woods, Joanna. Katerina: The Russian World of Katherine Mansfield. Auckland: Penguin, 2001.

\section{REFERENCES}

Berkman, Sylvia. Katherine Mansfield: A Critical Study. New Haven: Yale University, 1951; Christchurch: Whitcombe and Tombs, 1951.

Bowen, Elizabeth. 'A Living Writer.' Cornhill Magazine, 1010 (Winter 1956-57): 121134.

Brewster, Dorothy and Angus Burrell. Dead Reckonings in Fiction. New York: Longmans, Green, 1924.

Burgan, Mary. Illness, Gender, and Writing: The Case of Katherine Mansfield. Baltimore: Johns Hopkins University, 1994.

Daly, Saralyn. Katherine Mansfield. Twayne English Author Series 23. New York: Twayne, 1965.

Gurr, Andrew. Writers in Exile. Brighton: Harvester, 1981.

Hankin, Cherry. Katherine Mansfield and her Confessional Stories. London: Macmillan, 1983; New York: St Martin's, 1983.

Hanson, Clare and Andrew Gurr. Katherine Mansfield. London: Macmillan, 1981.

Hormasji. Nariman. Katherine Mansfield: An Appraisal. Auckland: Collins, 1967.

Kaplan, Sydney Janet. Katherine Mansfield and the Origins of Modern Fiction. Ithaca, N. Y.: Cornell University, 1991.

Magalaner, Marvin. The Fiction of Katherine Mansfield. Carbondale, III.: Southern Illinois University, 1971; London: Fetter and Simons, 1971.

Michel, Paulette and Michel Dupuis, eds. The Fine Instrument. Sydney: Dangaroo, 1989.

Murry, John Middleton. Katherine Mansfield and Other Literary Portraits. London: P. Nevill, 1949.

Murry. Katherine Mansfield and Other Literary Studies. London: Constable 1959.

O'Connor, Frank. The Lonely Voice. London: Macmillan, 1965.

O'Sullivan, Vincent. 'The Magnetic Chain: Notes and Approaches to KM.' Landfall: The New Zealand Quarterly, 114 (June 1975): 95-131.

Pilditch, Jan, ed. The Critical Response to Katherine Mansfield. Westport, Conn: Greenwood, 1996.

Robinson, Roger, ed. Katherine Mansfield: In from the Margin. Baton Rouge: Louisiana State University, 1994.

Sewell, Arthur. Katherine Mansfield: A Critical Essay. Auckland: Unicorn, 1936.

\section{PAPERS}

The principal collection of manuscript material, particularly of Mansfield's letters and notebooks, is at the Alexander Turnbull Library, now part of the National Library in Wellington, New Zealand. Important collections are also held by the Newberry Library in Chicago, the Harry Ransom Humanities Research Center of the University of Texas at Austin and the British Library, Department of Manuscripts, London. A few items are held by the Assumption University Library, Windsor, Ontario; the Henry W. and Albert A. Berg Collection of the New York Public Library; the Huntington Library, 
San Marino, California; King's College London, Department of French, Adam Archive; the McMaster University Library, Hamilton, Ontario; the Mitchell Library, Sydney; the Smith College Library Rare Book Room, Northampton, Massachusetts; Stanford University Library, Special Collections, Palo Alto, California; the Strachey Trust, London and the Library of Sussex University. A small number of manuscripts are privately owned. 